\title{
Increased periostin associates with greater airflow limitation in patients receiving inhaled corticosteroids.
}

\author{
AUTHOR(S): \\ Kanemitsu, Yoshihiro; Matsumoto, Hisako; Izuhara, Kenji; \\ Tohda, Yuji; Kita, Hideo; Horiguchi, Takahiko; Kuwabara, \\ Kazunobu; ... Yokoyama, Tetsuji; Niimi, Akio; Mishima, \\ Michiaki
}

\section{CITATION:}

Kanemitsu, Yoshihiro ...[et al]. Increased periostin associates with greater airflow limitation in patients receiving inhaled corticosteroids.. The Journal of allergy and clinical immunology 2013, 132(2): 305-312.e3

\section{ISSUE DATE:}

2013-08

URL:

http://hdl.handle.net/2433/179319

\section{RIGHT:}

(C) 2013 American Academy of Allergy, Asthma \& Immunology.

Published by Mosby, Inc.; この論文は出版社版でありません。引用の際 には出版社版をご確認ご利用ください。; This is not the published version. Please cite only the published version. 
1 Increased periostin associates with greater airflow limitation in patients receiving

2 inhaled corticosteroids

3

4 Yoshihiro Kanemitsu MD*1,2 ${ }^{*}$, Hisako Matsumoto MD, PhD ${ }^{* 1,2}$, Kenji Izuhara MD,PhD ${ }^{3}$,

$5 \quad$ Yuji Tohda MD, $\mathrm{PhD}^{2,4}$, Hideo Kita MD, $\mathrm{PhD}^{2,5}$, Takahiko Horiguchi MD, $\mathrm{PhD}^{2,6}$, Kazunobu

6 Kuwabara MD, $\mathrm{PhD}^{2,6}$, Keisuke Tomii MD, $\mathrm{PhD}^{2,7}$, Kojiro Otsuka MD, $\mathrm{PhD}^{1,2,7}$, Masaki

$7 \quad$ Fujimura $\mathrm{MD}, \mathrm{PhD}^{2,8}$, Noriyuki Ohkura $\mathrm{MD}^{2,8}$, Katsuyuki Tomita $\mathrm{MD}, \mathrm{PhD}^{2,4}$, Akihito

8 Yokoyama MD, $\mathrm{PhD}^{2,9}$, Hiroshi Ohnishi MD, $\mathrm{PhD}^{2,9}$, Yasutaka Nakano MD, $\mathrm{PhD}^{2,10}$, Tetsuya

9 Oguma MD, $\mathrm{PhD}^{2,10}$, Soichiro Hozawa MD, $\mathrm{PhD}^{2,11}$, Tadao Nagasaki $\mathrm{MD}^{1}$, Isao Ito MD,

$10 \mathrm{PhD}^{1}$, Tsuyoshi Oguma MD ${ }^{1}$, Hideki Inoue $\mathrm{MD}^{1}$, Tomoko Tajiri MD ${ }^{1}$, Toshiyuki Iwata $\mathrm{MD}^{1}$,

11 Yumi Izuhara $\mathrm{MD}^{1}$, Junya Ono $\mathrm{BS}^{12}$, Shoichiro Ohta MD, $\mathrm{PhD}^{13}$, Mayumi Tamari MD,

$12 \mathrm{PhD}^{14}$, Tomomitsu Hirota DDS, $\mathrm{PhD}^{14}$, Tetsuji Yokoyama MD, $\mathrm{PhD}^{15}$, Akio Niimi MD,

$13 \mathrm{PhD}^{1,2,16}$ and Michiaki Mishima MD, $\mathrm{PhD}^{1,2}$

${ }^{1}$ Department of Respiratory Medicine, Graduate School of Medicine, Kyoto University,

16 Kyoto, Japan

$17 \quad{ }^{2}$ Kinki Hokuriku Airway disease Conference (KiHAC)

$18{ }^{3}$ Division of Medical Biochemistry, Department of Biomolecular Sciences, Saga Medical

19 School, Saga, Japan

$20{ }^{4}$ Department of Respiratory Medicine and Allergology, Faculty of Medicine, Kinki University,

21 Osaka, Japan

$22{ }^{5}$ Department of Respiratory Medicine, Takatsuki Red Cross Hospital, Osaka, Japan

$23{ }^{6}$ Department of Respiratory Internal Medicine, Fujita Health University Second Educational

24 Hospital, Aichi, Japan

$25{ }^{7}$ Department of Respiratory Medicine, Kobe City Medical Center General Hospital, Hyogo,

26 Japan

$27{ }^{8}$ Department of Respiratory Medicine, Cellular Transplantation Biology, Kanazawa 
University Graduate School of Medicine, Kanazawa, Japan

$29{ }^{9}$ Department of Hematology and Respiratory Medicine, Kochi University, Kochi, Japan

$30{ }^{10}$ Division of Respiratory Medicine, Department of Internal Medicine, Shiga University of

31 Medical Science, Shiga, Japan

${ }^{11}$ Hiroshima Allergy and Respiratory Clinic, Hiroshima, Japan

${ }^{12}$ Shino-Test Corporation, Kanagawa, Japan

${ }^{13}$ Department of Laboratory Medicine, Saga Medical School, Saga, Japan

${ }^{14}$ Laboratory for Respiratory Diseases, Center for Genomic Medicine, RIKEN, Yokohama,

Kanagawa, Japan

${ }^{15}$ Department of Health Promotion, National Institute of Public Health, Wako, Saitama, Japan

${ }^{16}$ Department of Medical Oncology and Immunology, Nagoya City University School of

Medical Sciences, Aichi, Japan

40

*YK and HM contributed equally to this study.

Correspondence should be addressed to Hisako Matsumoto MD, PhD

Department of Respiratory Medicine, Graduate School of Medicine, Kyoto University

53 Kawahara-cho, Shogoin, Sakyo-ku, Kyoto 606-8507, Japan

E-mail: hmatsumo@kuhp.kyoto-u.ac.jp

46 Funded by KiHAC, as a project of 2009 KiHAC Respiratory Medicine Group and the 


\section{Abstract}

Background: Periostin, an extracellular matrix protein, contributes to subepithelial thickening in asthmatic airways, and its serum levels reflect airway eosinophilic inflammation. However, the relationship between periostin and the development of airflow limitation, a functional consequence of airway remodeling, remains unknown.

Objective: To determine the relationship between serum periostin levels and pulmonary function decline in asthmatic patients on inhaled corticosteroid (ICS) treatment. Methods: 224 asthmatic patients (average age 62.3 years) treated with ICS for at least 4 years were enrolled. Annual changes in forced expiratory volume in one second $\left(\mathrm{FEV}_{1}\right)$, from at least one year after the initiation of ICS treatment to the time of enrollment or later (average 16.2 measurements over 8 years per individual), were assessed. At enrollment, clinical indices, biomarkers including serum periostin, and periostin gene polymorphisms were examined. Associations between clinical indices or biomarkers and a decline in $\mathrm{FEV}_{1}$ of $30 \mathrm{~mL} \cdot \mathrm{yr}^{-1}$ or greater were analyzed.

Results: High serum periostin levels $(\geq 95 \mathrm{ng} / \mathrm{mL})$ at enrollment, the highest treatment step, higher ICS daily doses, a history of admission due to asthma exacerbation, comorbid or a history of sinusitis, and ex-smoking were associated with a decline in $\mathrm{FEV}_{1}$ of $30 \mathrm{~mL} \cdot \mathrm{yr}^{-1}$ or greater. Multivariate analysis revealed that high serum periostin, the highest treatment step, and ex-smoking were independent risk factors for the decline. Polymorphisms of periostin gene were related to higher serum periostin levels (rs3829365) and a decline in $\mathrm{FEV}_{1}$ of 30 $\mathrm{mL} \cdot \mathrm{yr}^{-1}$ or greater (rs9603226).

Conclusions: Serum periostin appears to be a useful biomarker for the development of airflow limitation in asthmatic patients on ICS.

\section{Clinical implications ( 25 words)}

Serum periostin levels reflect greater $\mathrm{FEV}_{1}$ decline in asthmatic patients on inhaled 
74 corticosteroid treatment. POSTN gene polymorphisms may also be helpful for identifying

75 rapid $\mathrm{FEV}_{1}$ decliners.

\section{$76 \quad$ Key words}

77 Asthma, inhaled corticosteroids, lung function decline, periostin, POSTN gene polymorphism,

78 sinusitis, treatment step

79

80 Abbreviations

81 ACT: asthma control test

82 ECP: eosinophil cationic protein

83 FAS I: fasciclin I

$84 \mathrm{FEV}_{1}$ : forced expiratory volume in one second

85 FVC: forced vital capacity

86 hsCRP: high sensitivity C-reactive protein

87 ICS: inhaled corticosteroids

88 IgE: immunoglobulin E

89 IL: interleukin

90 ROC: receiver operating characteristic

91 SNP: single-nucleotide polymorphism

92 TGF- $\beta$ : transforming growth factor beta

93

94 Total word counts for the text and the abstract are 3800 and 258 words, respectively. 


\section{Capsule summary (32 words)}

96 This is the first study to identify a relationship between high serum periostin and greater

97 annual decline in $\mathrm{FEV}_{1}$, which sheds new light on serum periositin as a useful biomarker in 98 asthma. 


\section{Introduction}

Airway inflammation and remodeling are key features of asthma that have been demonstrated by pathological ${ }^{1}$ and radiological findings ${ }^{2,3}$. Physiologically, patients with asthma show a greater decline in pulmonary function than subjects without asthma ${ }^{4}$. Studies that were mostly conducted in the era before inhaled corticosteroids (ICS) demonstrated that more severe symptoms or severe exacerbations ${ }^{5-7}$, long-standing asthma ${ }^{8}$, and smoking history ${ }^{4,8}$ were moderate to strong risk factors for greater decline in pulmonary function ${ }^{5}$. Blood and sputum eosinophilia ${ }^{9,10}$ and genetic predisposition ${ }^{11-13}$ were also potential risk factors. Owing to early intervention with ICS, however, airway inflammation and the degree of annual decline in pulmonary function have been attenuated in a majority of asthmatic patients $^{14-16}$. Meanwhile, a subset of patients still show accelerated decline in $\mathrm{FEV}_{1}$ and develop irreversible airway obstruction despite adequate treatment ${ }^{17,18}$. van Veen et al. found that exhaled nitric oxide of $20 \mathrm{ppb}$ or higher is a predictor of accelerated decline in pulmonary function in patients with difficult-to-treat asthma ${ }^{18}$. However, other biomarkers for greater decline in $\mathrm{FEV}_{1}$ despite treatment with ICS remain unknown.

The airway inflammation of asthma is classically characterized by infiltration and activation of eosinophils, mast cells, and Th2 cells with several mediators and Th2 cytokines, such as interleukin (IL)-4, IL-5, and IL-13 ${ }^{19,20}$. Periostin, a secreted, 90-kDa, extracellular matrix protein that is induced by IL-4 and IL-13, was originally isolated as an osteoblastspecific factor; it shares structural homology to the insect cell adhesion molecule fasciclin I (FAS I) and binds to fibronectin, tenascin-C, and collagen ${ }^{21,22}$. In airway epithelial cells collected from patients with asthma, periostin is one of the up-regulated genes ${ }^{23}$, and its expression is correlated with thickness of the airway basement membrane ${ }^{24}$. Takayama et al. clearly demonstrated that periostin is deposited in the airway subepithelial layer in asthmatic patients. Moreover, serum periostin is identified as the single best predictor of airway eosinophilia in patients with severe asthma who remain symptomatic despite maximal ICS 
125 treatment ${ }^{25}$. Therefore, we hypothesized that periostin would be a novel biomarker of

126 Th2/eosinophil-driven airway inflammation and greater decline in pulmonary function, a

127 functional consequence of airway remodeling in patients with asthma.

128 In this study, the effects of biomarkers and clinical indices on greater annual decline

129 in pulmonary function in asthmatic patients on ICS treatment were examined, with the

130 specific aim of determining the association between serum periostin levels and pulmonary

131 function decline. Polymorphisms of the POSTN gene, which encodes periostin, were also

132 examined on the hypothesis that POSTN gene polymorphisms may affect serum periostin

133 levels. 
Methods

\section{For full details see Online Repository}

136

137

138

139

140

\section{Patients}

Patients with asthma were recruited from nine institutions belonging to the Kinki Hokuriku Airway disease Conference where asthma specialists manage patients. Asthma was diagnosed according to the American Thoracic Society criteria ${ }^{26}$. From September 2009 to December 2011, patients were enrolled if they had received ICS treatment for 4 years or more, undergone three or more pulmonary function tests when they were stable, and were free from exacerbations for at least one month. The first pulmonary function test was performed at least one year after the commencement of ICS treatment and at 25 years of age or older. Patients who had smoked more than 10 pack-years, smoked in the past one year, or had other pulmonary diseases were excluded.

This study was approved by the ethics committee of each participant institution and was registered in the UMIN Clinical Trials Registry (Registry ID UMIN000002414). Written informed consent was obtained from all participants.

\section{Measurements}

At enrollment, patients underwent a work-up that included answering a selfcompleted questionnaire, spirometry, and blood tests. After enrollment, spirometry was repeated at least 6 months later for up to 12 months.

\section{Self-completed questionnaire and clinical indices}

The self-completed questionnaire was composed of 4 major items, as presented in Table 1. The Asthma Control Test (ACT) ${ }^{\mathrm{TM}}$ was also scored. The treatment step at enrollment was determined according to the Global Initiative for Asthma 2010 guideline ${ }^{27}$. 
160

161

162

163

164

165

166

167

168

169

170

171

172

173

174

175

176

177

178

179

180

181

182

183

184

\section{Pulmonary function}

Spirometry was performed using an electrical spirometer, which was calibrated once a week, at each institution. Spirometry data were obtained only when patients were stable. To determine pulmonary function on daily medications, ICS and other controllers, including long-acting $\beta_{2}$ agonists, leukotriene receptor antagonists, or slow-release theophylline, were not withdrawn before spirometry.

\section{Measurement of systemic biomarkers}

Blood eosinophil and neutrophil counts, and serum levels of total immunoglobulin E (IgE), specific IgE against common inhaled allergens, eosinophil cationic protein (ECP), high sensitivity C-reactive protein (hsCRP), and periostin were determined.

Serum periostin levels were measured using an enzyme-linked immunosorbent assay at Shino-test (Kanagawa, Japan), as described previously ${ }^{28}$. Pooled serum periostin level data from 66 healthy subjects [mean (SD), 60.7 (16.7) years old, 40 males] ${ }^{28,29}$ were used for comparison with those of asthmatic patients.

\section{Haplotype analysis, DNA extraction, and genotyping of the POSTN gene}

A total of 47 single-nucleotide polymorphisms (SNPs) in the region of the POSTN gene and its upstream, total $39 \mathrm{~kb}$, was captured in the HapMap Japanese data set. Haplotype analysis identified 4 major haplotypes and 2 minor haplotypes. Two minor haplotypes were grouped into the closest major haplotype, and 3 tag SNPs that determined the 4 haplotypes were identified (Figure 1).

Genomic DNA was isolated from blood cells using a QIAamp DNA Blood Mini Kit (Qiagen, Tokyo, Japan). SNPs were genotyped using a Taqman genotyping assay according to the manufacturer's instructions (Applied Biosystems, Tokyo, Japan) and analyzed using an Applied Biosystems 7300 Real-Time PCR System (Applied Biosystems). 
$187 \quad$ Statistical analysis

188 Statistical analyses were performed using JMP version 9.0 (SAS Institute Inc., Tokyo, 189 Japan). Annual changes in $\mathrm{FEV}_{1}\left(\Delta \mathrm{FEV}_{1}\right)$ were estimated for each subject by fitting a least190 square regression line to all of his/her all available data points. Receiver operating 191 characteristic (ROC) curve analysis was performed to determine a serum periostin cut-off 192 value for asthmatic patients. The effects of serum biomarkers or other indices on $\Delta F E V_{1}$ were 193 estimated using a generalized linear mixed model with adjustment for sex, height, age at 194 enrollment, and $\mathrm{FEV}_{1}$ at the first measurement. The institutions were included as random effects in this model. On univariate analysis of $\Delta \mathrm{FEV}_{1}$, the adjusted $\mathrm{p}$ value, i.e., $\mathrm{q}$ value, which was a measure of significance in terms of the false discovery rate, was obtained using $\mathrm{R}$ and QVALUE software ${ }^{30}$ to determine spurious significance in multiple testing. The effects on the dichotomous data for a decline in $\mathrm{FEV}_{1}$ of $-30 \mathrm{~mL} \cdot \mathrm{yr}^{-1}$ or greater ${ }^{31}$ were similarly estimated using a generalized linear mixed model by IBM SPSS Advanced Statistics 19 (SPSS Inc., Tokyo, Japan). Multivariate analysis was performed using variables with $\mathrm{p}<0.10$ on univariate analysis, except for ICS daily maintenance dose because of its strong correlation with treatment step. On multivariate analysis, the periostin level was considered as a dichotomous variable (high or low) instead of a continuous variable. Correlation coefficients between serum periostin levels and clinical indices were estimated by fitting least-square regression lines to data, in which institutions were included as random effects. Unpaired $t$ - and Chi-square tests were performed for comparisons of continuous and dichotomous variables, respectively. When data were not normally distributed, they were log- 


\section{Results}

\section{Patients' characteristics}

Initially, 233 patients were enrolled in this study, but 9 patients were excluded: 5 with a smoking history of more than 10 pack-years and 4 who did not have enough pulmonary function data available. The demographic data of the remaining 224 patients are presented in Table 2. The mean age at enrollment was 62.3 (13.7) years. Overall, $130(58 \%)$ had onset of asthma at 40 years or older. The average number of measurements of $\mathrm{FEV}_{1}$, follow-up period, and $\triangle \mathrm{FEV}_{1}$ of 224 patients were 16.2 (13.9) times, $8.0(4.5)$ years, and $-7.8(34.6) \mathrm{mL} \cdot \mathrm{yr}^{-1}$, respectively. The distribution of $\Delta \mathrm{FEV}_{1}$ in this population is shown in Figure E1 in the Online Repository. Within 2 years after diagnosis, $46 \%$ of patients started ICS treatment. At enrollment, $82 \%$ of patients took controllers such as long-acting $\beta_{2}$ agonists, leukotriene receptor antagonists, or sustained release theophylline to achieve adequate asthma control. Based on a questionnaire, adherence to medication was satisfactory; $49 \%$ of the participants never and 38\% seldom forgot to take ICS or other medications. Based on ACT scores, $50 \%$ was totally controlled, and $38 \%$ scored from 20 to 24 , indicating that they were well controlled at enrollment. higher than those of healthy subjects [39.1 (24.5) ng/mL, p < 0.001]. The ROC curve analysis was performed to discriminate patients with asthma who were thought to have refractory Th2 inflammation despite long-term ICS treatment from healthy subjects. The highest specificity among the 4 cut-off values tested was achieved at $95 \mathrm{ng} / \mathrm{mL}(0.985)$ in the comparison study of 224 asthmatic patients and 66 healthy subjects. Therefore a cut-off value of $95 \mathrm{ng} / \mathrm{mL}$ was used to define a high serum periostin group, although it had relatively lesser sensitivity (0.379) (see Figure E2 in the Online Repository). In asthmatic patients, 85 patients (38\%) had 
234 treatment step 4, according to the treatment step classification ${ }^{27}$, and 9 patients (11\%) were on treatment step 5 .

236

Associations between serum periostin levels and greater annual decline in $\mathrm{FEV}_{1}$ and a decline in $\mathrm{FEV}_{1}$ of $30 \mathrm{~mL} \cdot \mathrm{yr}^{-1}$ or greater

In an analysis of continuous values of $\triangle \mathrm{FEV}_{1}$, greater decline in $\mathrm{FEV}_{1}$ was associated with higher serum periostin levels at enrollment, treatment step 5, lower ACT scores, incomplete adherence to medications, comorbid or a history of sinusitis, and comorbid diabetes mellitus (Table 3). When patients were stratified into two groups according to their serum periostin levels, high serum periostin ( $\geq 95 \mathrm{ng} / \mathrm{mL}$ ) was also associated with greater decline in $\mathrm{FEV}_{1}$ (Table 3). Of these, high serum periostin was significant after controlling for multiple testing using the false discovery rate $(q=0.03$, data not shown in Table 3$) .{ }^{30}$

Multivariate analysis revealed that greater decline of $\mathrm{FEV}_{1}$ was solely associated with high serum periostin ( $\geq 95 \mathrm{ng} / \mathrm{mL}$ ) (estimated effect $-5.39,95 \%$ confidence interval -10.0 to -0.77 , $\mathrm{p}=0.02)$

Fifty-two patients $(23 \%)$ showed a decline in $\mathrm{FEV}_{1}$ of $30 \mathrm{~mL} \cdot \mathrm{yr}^{-1}$ or greater [mean -

$\left.51.8(18.4) \mathrm{mL} \cdot \mathrm{yr}^{-1}\right]$ and were considered rapid decliners ${ }^{31}$. When adjusted by confounders, higher serum periostin levels at enrollment, treatment step 5, a history of admission due to asthma exacerbation, higher ICS daily doses, comorbid or a history of sinusitis, and exsmoking were associated with a decline in $\mathrm{FEV}_{1}$ of $30 \mathrm{~mL} \cdot \mathrm{yr}^{-1}$ or greater. High serum periostin $(\geq 95 \mathrm{ng} / \mathrm{mL})$ was also associated with a decline in $\mathrm{FEV}_{1}$ of $30 \mathrm{~mL} \cdot \mathrm{yr}^{-1}$ or greater (Table 4).

Of the 224 patients, 19 patients were on treatment step 5, and 36 patients took high- 
260

261

262

263

264

265

266

267

268

269

270

271

272

273

274

275

276

277

278

279

280

281

282

283

patients were stratified into the high periostin group, the average $\triangle \mathrm{FEV}_{1}$ of patients on treatment step $5(\mathrm{n}=9)$ was $-41.0(49.3) \mathrm{mL} \cdot \mathrm{yr}^{-1}$, and 7 of them $(78 \%)$ had excess decline; the average $\triangle \mathrm{FEV}_{1}$ of patients on high-dose ICS $(\mathrm{n}=18)$ was $-34.3(39.4) \mathrm{mL} \cdot \mathrm{yr}^{-1}$, and 11 of them $(61 \%)$ had a decline in $\mathrm{FEV}_{1}$ of $30 \mathrm{~mL} \cdot \mathrm{yr}^{-1}$ or greater.

\section{Serum periostin levels and clinical indices}

In 224 patients, serum periostin levels were weakly associated with blood eosinophil counts (Figure 2), serum IgE (Figure 2) and ECP levels $(r=0.25, p=0.0005)$, ICS-untreated period, i.e. period between onset of asthma and the initiation of ICS therapy (r $=0.16, \mathrm{p}=0.01)$, daily maintenance doses of ICS at enrollment $(\mathrm{r}=0.13, \mathrm{p}=0.05)$, and a history of admission due to asthma exacerbation $(r=0.15, p=0.03)$. Serum periostin levels were significantly higher in patients on high-dose ICS ( $\geq 1,000 \mu \mathrm{g}$ daily) than in the remaining patients $(110.3 \mathrm{ng} / \mathrm{mL} v s .89 .5 \mathrm{ng} / \mathrm{mL}, \mathrm{p}=0.003)$. Lastly, serum periostin levels were higher in patients with sinusitis than in those without sinusitis $(103.9 \mathrm{ng} / \mathrm{mL}$ vs. 88.3 $\mathrm{ng} / \mathrm{mL}, \mathrm{p}=0.007)$. Serum periostin levels did not show any seasonal variability or association with age at onset of asthma (data not shown).

\section{POSTN gene polymorphisms}

Associations between polymorphisms of the POSTN gene, which encodes periostin, and both serum periostin levels and pulmonary function decline were then investigated. In one patient, DNA quality was insufficient for genotyping; thus, 3 tag SNPs of the POSTN gene were analyzed in 223 patients. All genotyped data were in Hardy-Weinberg equilibrium.

The frequencies of the 3 tag SNPs and analysis results using dominant and recessive models for serum periostin levels and a decline in $\mathrm{FEV}_{1}$ of $30 \mathrm{~mL} \cdot \mathrm{yr}^{-1}$ or greater are presented in Table 5 .

Serum periostin levels were higher in patients with the GG genotype of rs3829365 than 
286 in those with the GC/CC genotype (GG $98.7 \mathrm{ng} / \mathrm{mL} v s . \mathrm{GC} / \mathrm{CC} 86.1 \mathrm{ng} / \mathrm{mL}, \mathrm{p}=0.003$ ).

287 rs 1028728 was not associated with serum periostin levels or with the frequency of rapid

288 decliners, but patients with the TT genotype of rs1028728, 4 patients only, showed no

289 significant decline compared with the AA/AT genotype (AA/AT -8.6 $\mathrm{mL} \cdot \mathrm{yr}^{-1}$ vs. TT 29.3

$290 \mathrm{~mL} \cdot \mathrm{yr}^{-1}, \mathrm{p}=0.03$ ). Rapid decliners were more frequently observed in patients with the minor

291 A allele of rs9603226 than in the GG genotype (GG 16\% vs. AG/AA 30\%, p = 0.02). A

292 marked difference in the frequency of rapid decliners was observed when patients were

293 stratified into the high periostin group [GG of rs9630226 $(\mathrm{n}=37) 19 \%$ vs. AG/AA $(n=47)$

$29445 \%, p=0.01]$ 
295

296

297

298

299

300

301

302

303

304

305

306

307

308

309

310

311

312

313

\section{Discussion}

To the best of our knowledge, this is the first study to identify a relationship between greater decline in $\mathrm{FEV}_{1}$ and higher serum periostin levels, particularly if they were $95 \mathrm{ng} / \mathrm{mL}$ or more, in asthmatic patients on ICS treatment. It was also shown that high serum periostin, together with treatment step 5 and light ex-smoking, was an independent risk factor for a decline in $\mathrm{FEV}_{1}$ of $30 \mathrm{~mL} \cdot \mathrm{yr}^{-1}$ or greater. In addition, polymorphisms of the POSTN gene, which encodes periostin, were associated with serum periostin levels and a decline in $\mathrm{FEV}_{1}$ of $30 \mathrm{~mL} \cdot \mathrm{yr}^{-1}$ or greater in asthmatic patients. These findings suggest that serum periostin may be a useful biomarker for the development of airflow limitation in asthmatic patients on ICS.

In this study, despite long-term treatment with ICS with or without other controllers, $23 \%$ of asthmatic patients were rapid decliners who showed a decline in $\mathrm{FEV}_{1}$ of $30 \mathrm{~mL} \cdot \mathrm{yr}^{-1}$ or greater, for which treatment step 5 was an independent risk factor. Adherence to ICS treatment and the frequency of early intervention with ICS did not differ between rapid decliners and non-decliners, although long-term adherence to ICS was undetermined in the present study. In previous studies of patients who were not treated with ICS, severe exacerbation of asthma contributed to greater annual decline of pulmonary function ${ }^{6,7}$, but the exacerbation-related greater annual decline disappeared in an early intervention group with ICS treatment in the START study ${ }^{6}$, which might be interpreted to mean that asthmatic patients on ICS treatment have little risk of accelerated $\mathrm{FEV}_{1}$ decline. However, since the START study originally recruited mild persistent asthmatic patients, its results cannot simply be applied to severe asthmatic patients. As observed in the present study, there would be a subset of asthmatic patients still at risk of greater annual decline of pulmonary function despite intensive treatment for asthma.

Persistent eosinophilic airway inflammation is a key process in irreversible airway obstruction $^{10}$. Indeed, exhaled nitric oxide of $20 \mathrm{ppb}$ or higher is a risk factor for accelerated 
$321 \mathrm{FEV}_{1}$ decline in patients with difficult-to-treat asthma ${ }^{18}$. Studies on novel therapies for

322 refractory eosinophilic asthma, i.e., anti-IL-5 therapy ${ }^{32}$ and anti-IL-13 therapy ${ }^{33}$, revealed that

323 these treatments may reverse airway remodeling when patients are adequately targeted,

324 suggesting the necessity of establishing "companion diagnostics" for this population.

325 According to the most recent study, serum periostin is the single best biomarker reflecting sputum and tissue eosinophilia among several biomarkers, including blood eosinophils and exhaled nitric oxide ${ }^{25}$. In the current study, the serum periostin level, which was associated with the blood eosinophil count, was the sole biomarker that reflected greater decline in $\mathrm{FEV}_{1}$. Periostin is secreted by airway epithelial cells ${ }^{23,24}$ and lung fibroblasts ${ }^{21}$ in response to IL-4 and IL-13 and is thought to be secreted into the capillary vessels. Downstream of IL-13, which plays a pivotal role in subepithelial airway fibrosis ${ }^{34}$, airway remodeling ${ }^{35}$, and steroid insensitivity $^{36}$, periostin mediates collagen synthesis ${ }^{24}$ and fibrillogenesis ${ }^{24,37}$ by binding to collagen $^{37}$ and activates TGF- $\beta^{24}$. In the asthmatic airway, periostin is deposited in the subepithelial layer, colocalizing with collagens I, III, and V, fibronectin, tenascin-C, and periostin itself ${ }^{21}$, which indicates involvement of periostin in airway remodeling in asthma. Collectively, periostin may be a key molecule that links eosinophilic inflammation and remodeling via IL-13 in asthmatic airways. Further roles of periostin in allergic inflammation and remodeling in the airways remain undetermined because studies using periostin-deficient mice with acute allergen exposure have yielded conflicting findings ${ }^{38-40}$; one study showed that periostin facilitates eosinophil infiltration into the lung ${ }^{38}$, whereas two other studies ${ }^{39,40}$ suggested protective roles of periostin. Meanwhile, a recent study of a chronic mouse model of atopic dermatitis demonstrated periostin's role in the chronicity of Th2 inflammation ${ }^{29}$. In the present study, patients on high-dose ICS showed higher serum periostin levels than the other patients. Although a longitudinal study is needed to determine responses of serum periostin levels to ICS treatment, we do not think that the high serum periostin levels in patients on high-dose ICS were induced by ICS treatment, because periostin expression in 
the airway epithelium was decreased with ICS treatment ${ }^{23}$. Rather, the elevation of serum periostin in this population may reflect IL-13-mediated inflammation that is partly refractory to ICS, as was reported in a recent study by Jia and colleagues ${ }^{25}$. They showed that, in patients with severe asthma who were treated with high doses ICS (> $1000 \mu \mathrm{g}$ daily), elevation of serum periostin levels was associated with persistent airway tissue eosinophilia, concluding that serum periostin is a systemic biomarker of airway eosinophilia refractory to high-dose ICS ${ }^{25}$. Providing further support, among patients with moderate to severe asthma who are inadequately controlled despite ICS treatment, patients with high serum periostin levels are likely to benefit from anti-IL-13 antibody, lebrikizumab, treatment ${ }^{33}$. The novelty of the present finding is that high serum periostin is an independent risk factor for greater decline in $\mathrm{FEV}_{1}$, providing the first evidence for the potential association between persistent Th2- or IL-13-driven inflammation refractory to ICS treatment and greater decline in $\mathrm{FEV}_{1}$, a functional consequence of airway remodeling.

Needless to say, current smokers with asthma have more accelerated $\mathrm{FEV}_{1}$ decline $^{4}$ than those not smoking, and current smoking impairs the therapeutic response to ICS or oral corticosteroids $^{41}$. Meanwhile, smoking cessation improves their $\mathrm{FEV}_{1}$ levels ${ }^{42}$, and exsmokers with asthma with 10 pack-years or more show an intermediate response to shortterm oral corticosteroid treatment, between current smokers and never-smokers ${ }^{41}$. In the present study, rather unexpectedly, ex-smoking with 10 pack-years or less was still an independent risk factor for a decline in $\mathrm{FEV}_{1}$ of $30 \mathrm{~mL} \cdot \mathrm{yr}^{-1}$ or greater. It should be recognized that even light ex-smoking increases the risk of airway remodeling in asthmatic patients on ICS, and its underlying mechanisms should be clarified.

Chronic sinusitis is a well-known comorbidity with severe asthma ${ }^{43,44}$. In the present study, rapid decliners were more frequently observed in asthmatic patients with sinusitis than those without sinusitis on univariate analysis, and their periostin levels were higher than in patients without sinusitis. In the present study, polypoid lesions in the sinuses were not 
evaluated by otolaryngologists at enrollment. However, considering that periostin is upregulated in nasal polyp tissue in patients with chronic rhinosinusitis ${ }^{45}$, asthmatic patients with sinusitis may have had severe upper and lower airway inflammation with persistent increases in periostin expression, which may have resulted in a decline in $\mathrm{FEV}_{1}$ of $30 \mathrm{~mL} \cdot \mathrm{yr}^{-1}$ or greater. Periostin is a potential molecule that unifies sinusitis and severe asthma.

Periostin is encoded on the POSTN gene, which is located on chromosome 13q13.3. rs3829365, which is located at the 5'UTR region that may contain sequences to regulate translation efficiency or mRNA stability, was associated with serum periostin levels. This finding suggests that, besides IL-13, a master regulator of periostin, genetic background partly determines periostin levels, although a replication study would be necessary to confirm this. The minor A allele of rs9603226, located 66 bp upstream of exon 21 in the C-terminal region, was associated with a decline in $\mathrm{FEV}_{1}$ of $30 \mathrm{~mL} \cdot \mathrm{yr}^{-1}$ or greater. In periostin, FAS I domains are thought to be primary binding sites to fibronectin, tenascin- $\mathrm{C}$, and collagen $\mathrm{V}^{21}$, whereas the C-terminal region in its intact form may down-regulate the binding activity of periostin to these extracellular matrix proteins ${ }^{21}$. We therefore speculate that the minor A allele of rs9603226 might modify the binding activity at the C-terminal region and facilitate airway remodeling, particularly if the airway is in periostin enriched milieu. Further studies are needed to clarify if these SNPs are functional variants.

The age of patients in this study appears to be older than in other Euro-American studies $^{6,7,14,18,20,23,25}$. One reason for the age distribution would be the entry criteria of this study. Another reason would be explained by population aging including population with asthma in Japan. According to a patient survey by the Japanese Ministry of Health, Labour and Welfare in 2008, patients aged 70 to 74 years were the most frequent age group of adult patients with asthma ${ }^{46}$, which is still older than the average age of patients in this study. There are several limitations to the present study. First, since this study was observational in nature, ICS doses and numbers or types of controllers were not fixed during 
399

400

401

402

403

404

405

406

407

408

409

410

411

412

413

the follow-up period. Controllers such as long-acting $\beta_{2}$ agonists were not withdrawn at pulmonary function testing to evaluate function on daily medications, which may have resulted in the small average $\Delta \mathrm{FEV}_{1},-7.8 \mathrm{~mL} \cdot \mathrm{yr}^{-1}$. Meanwhile, averages of 16.2 measurements of $\mathrm{FEV}_{1}$ and 8.0 years of follow-up were satisfactory for a longitudinal analysis of pulmonary function ${ }^{47}$, and $\triangle \mathrm{FEV}_{1}$ was normally distributed. Secondly, serum biomarkers were measured only once at enrollment, but the significant associations between POSTN gene polymorphisms and serum periostin levels or a decline in $\mathrm{FEV}_{1}$ of $30 \mathrm{~mL} \cdot \mathrm{yr}^{-1}$ or greater may circumvent the inherent insufficiency of single measurement of serum periostin. Thirdly, most of the clinical information, including smoking history and chronic sinusitis, was based on a self-completed questionnaire, which might be biased by recall memory. Despite these limitations, the current findings may provide directions for future research.

In conclusion, serum periostin appears to be a useful biomarker that reflects the development of airflow limitation in patients on prolonged treatment with ICS. POSTN gene polymorphisms may also be helpful for identification of rapid decliners. 


\section{Acknowledgments}

415 The authors would like to acknowledge Dr Nobuo Ohta, Department of

416 Otolaryngology, Head and Neck Surgery, Yamagata University for fruitful discussion on

417 periostin expression in nasal tissue of chronic sinusitis. The authors would also like to thank

418 Ms Maki Futamata (Saga Medical School), Dr Guergana Petrova Stoyanoya, Dr Cui Shilei,

419 Ms Aya Inazumi, and Ms Yuko Maeda (Kyoto University) for their technical assistance. 
Reference

1. Pascual RM, Peters SP. Airway remodeling contributes to the progressive loss of lung function in asthma: an overview. J Allergy Clin Immunol 2005; 116:477-86; quiz 87.

2. Niimi A, Matsumoto H, Takemura M, Ueda T, Chin K, Mishima M. Relationship of airway wall thickness to airway sensitivity and airway reactivity in asthma. Am J Respir Crit Care Med 2003; 168:983-8.

3. Ueda T, Niimi A, Matsumoto H, Takemura M, Hirai T, Yamaguchi M, et al. Role of small airways in asthma: investigation using high-resolution computed tomography. $\mathbf{J}$ Allergy Clin Immunol 2006; 118:1019-25.

4. Lange P, Parner J, Vestbo J, Schnohr P, Jensen G. A 15-year follow-up study of ventilatory function in adults with asthma. N Engl J Med 1998; 339:1194-200.

5. Ulrik CS. Outcome of asthma: longitudinal changes in lung function. Eur Respir J 1999; 13:904-18.

6. O'Byrne PM, Pedersen S, Lamm CJ, Tan WC, Busse WW, Group SI. Severe exacerbations and decline in lung function in asthma. Am J Respir Crit Care Med 2009; 179:19-24.

7. Bai TR, Vonk JM, Postma DS, Boezen HM. Severe exacerbations predict excess lung function decline in asthma. Eur Respir J 2007; 30:452-6.

8. Ulrik CS, Lange P. Decline of lung function in adults with bronchial asthma. Am J Respir Crit Care Med 1994; 150:629-34.

9. Ulrik CS, Backer V, Dirksen A. A 10 year follow up of 180 adults with bronchial asthma: factors important for the decline in lung function. Thorax 1992; 47:14-8.

10. ten Brinke A, Zwinderman AH, Sterk PJ, Rabe KF, Bel EH. Factors associated with persistent airflow limitation in severe asthma. Am J Respir Crit Care Med 2001; 164:744-8.

11. Jongepier H, Boezen HM, Dijkstra A, Howard TD, Vonk JM, Koppelman GH, et al. Polymorphisms of the ADAM33 gene are associated with accelerated lung function decline in asthma. Clin Exp Allergy 2004; 34:757-60.

12. Koppelman GH, Sayers I. Evidence of a genetic contribution to lung function decline in asthma. J Allergy Clin Immunol 2011; 128:479-84.

13. Tantisira KG, Lasky-Su J, Harada M, Murphy A, Litonjua AA, Himes BE, et al. Genomewide association between GLCCI1 and response to glucocorticoid therapy in asthma. N Engl J Med 2011; 365:1173-83.

14. Dijkstra A, Vonk JM, Jongepier H, Koppelman GH, Schouten JP, ten Hacken NH, et al. Lung function decline in asthma: association with inhaled corticosteroids, smoking and sex. Thorax 2006; 61:105-10.

15. O'Byrne PM, Pedersen S, Busse WW, Tan WC, Chen YZ, Ohlsson SV, et al. Effects of early intervention with inhaled budesonide on lung function in newly diagnosed 
asthma. Chest 2006; 129:1478-85.

16. Selroos O, Löfroos AB, Pietinalho A, Riska H. Asthma control and steroid doses 5 years after early or delayed introduction of inhaled corticosteroids in asthma: a reallife study. Respir Med 2004; 98:254-62.

17. de Marco R, Marcon A, Jarvis D, Accordini S, Bugiani M, Cazzoletti L, et al. Inhaled steroids are associated with reduced lung function decline in subjects with asthma with elevated total IgE. J Allergy Clin Immunol 2007; 119:611-7.

18. van Veen IH, Ten Brinke A, Sterk PJ, Sont JK, Gauw SA, Rabe KF, et al. Exhaled nitric oxide predicts lung function decline in difficult-to-treat asthma. Eur Respir J 2008; 32:344-9.

19. Levine SJ, Wenzel SE. Narrative review: the role of Th2 immune pathway modulation in the treatment of severe asthma and its phenotypes. Ann Intern Med 2010; 152:2327.

20. Woodruff PG, Modrek B, Choy DF, Jia G, Abbas AR, Ellwanger A, et al. T-helper type 2-driven inflammation defines major subphenotypes of asthma. Am J Respir Crit Care Med 2009; 180:388-95.

21. Takayama G, Arima K, Kanaji T, Toda S, Tanaka H, Shoji S, et al. Periostin: a novel component of subepithelial fibrosis of bronchial asthma downstream of IL-4 and IL13 signals. J Allergy Clin Immunol 2006; 118:98-104.

22. Kii I, Nishiyama T, Li M, Matsumoto K, Saito M, Amizuka N, et al. Incorporation of tenascin- $\mathrm{C}$ into the extracellular matrix by periostin underlies an extracellular meshwork architecture. J Biol Chem 2010; 285:2028-39.

23. Woodruff PG, Boushey HA, Dolganov GM, Barker CS, Yang YH, Donnelly S, et al. Genome-wide profiling identifies epithelial cell genes associated with asthma and with treatment response to corticosteroids. Proc Natl Acad Sci U S A 2007; 104:15858-63.

24. Sidhu SS, Yuan S, Innes AL, Kerr S, Woodruff PG, Hou L, et al. Roles of epithelial cell-derived periostin in TGF-beta activation, collagen production, and collagen gel elasticity in asthma. Proc Natl Acad Sci U S A 2010; 107:14170-5.

25. Jia G, Erickson RW, Choy DF, Mosesova S, Wu LC, Solberg OD, et al. Periostin is a systemic biomarker of eosinophilic airway inflammation in asthmatic patients. $\mathrm{J}$ Allergy Clin Immunol 2012; 130: 647-54.

26. Standards for the diagnosis and care of patients with chronic obstructive pulmonary disease (COPD) and asthma. This official statement of the American Thoracic Society was adopted by the ATS Board of Directors, November 1986. Am Rev Respir Dis 1987; 136:225-44.

27. Global Strategy for Asthma Management and Prevention, Global Initiative for Asthma (GINA) 2010. Available from: Global Strategy for Asthma Management and 
496

497

498

499

500

501

502

503

504

505

506

507

508

509

510

511

512

513

514

515

516

517

518

519

520

521

522

523

524

525

526

527

528

529

530

531

532

533

Prevention, Global Initiative for Asthma (GINA) 2010. Available from: http://www.ginasthma.org.

28. Okamoto M, Hoshino T, Kitasato Y, Sakazaki Y, Kawayama T, Fujimoto K, et al. Periostin, a matrix protein, is a novel biomarker for idiopathic interstitial pneumonias. Eur Respir J 2011; 37:1119-27.

29. Masuoka M, Shiraishi H, Ohta S, Suzuki S, Arima K, Aoki S, et al. Periostin promotes chronic allergic inflammation in response to Th2 cytokines. J Clin Invest 2012; 122:2590-600.

30. Storey JD, Tibshirani R. Statistical significance for genomewide studies. Proc Natl Acad Sci U S A 2003; 100:9440-5.

31. Broekema M, Volbeda F, Timens W, Dijkstra A, Lee NA, Lee JJ, et al. Airway eosinophilia in remission and progression of asthma: accumulation with a fast decline of $\mathrm{FEV}_{1}$. Respir Med 2010; 104:1254-62.

32. Haldar P, Brightling CE, Hargadon B, Gupta S, Monteiro W, Sousa A, et al. Mepolizumab and exacerbations of refractory eosinophilic asthma. N Engl J Med 2009; 360:973-84.

33. Corren J, Lemanske RF, Hanania NA, Korenblat PE, Parsey MV, Arron JR, et al. Lebrikizumab treatment in adults with asthma. N Engl J Med 2011; 365:1088-98.

34. Zhu Z, Homer RJ, Wang Z, Chen Q, Geba GP, Wang J, et al. Pulmonary expression of interleukin-13 causes inflammation, mucus hypersecretion, subepithelial fibrosis, physiologic abnormalities, and eotaxin production. J Clin Invest 1999; 103:779-88.

35. Elias JA, Zhu Z, Chupp G, Homer RJ. Airway remodeling in asthma. J Clin Invest 1999; 104:1001-6.

36. Saha SK, Berry MA, Parker D, Siddiqui S, Morgan A, May R, et al. Increased sputum and bronchial biopsy IL-13 expression in severe asthma. J Allergy Clin Immunol 2008; 121:685-91.

37. Norris RA, Damon B, Mironov V, Kasyanov V, Ramamurthi A, Moreno-Rodriguez R, et al. Periostin regulates collagen fibrillogenesis and the biomechanical properties of connective tissues. J Cell Biochem 2007; 101:695-711.

38. Blanchard C, Mingler MK, McBride M, Putnam PE, Collins MH, Chang G, et al. Periostin facilitates eosinophil tissue infiltration in allergic lung and esophageal responses. Mucosal Immunol 2008; 1:289-96.

39. Gordon ED, Sidhu SS, Wang ZE, Woodruff PG, Yuan S, Solon MC, et al. A protective role for periostin and TGF- $\beta$ in IgE-mediated allergy and airway hyperresponsiveness. Clin Exp Allergy 2012; 42:144-55.

40. Sehra S, Yao W, Nguyen ET, Ahyi AN, Tuana FM, Ahlfeld SK, et al. Periostin regulates goblet cell metaplasia in a model of allergic airway inflammation. $\mathrm{J}$ Immunol 2011; 186:4959-66. 
534 41. Thomson NC, Chaudhuri R, Livingston E. Asthma and cigarette smoking. Eur Respir

535

536

537

538

539

540

541

542

543

544

545

546

547

548

549

550

551

552

553

554 J 2004; 24:822-33.

42. Chaudhuri R, Livingston E, McMahon AD, Lafferty J, Fraser I, Spears M, et al. Effects of smoking cessation on lung function and airway inflammation in smokers with asthma. Am J Respir Crit Care Med 2006; 174:127-33.

43. Dixon AE, Kaminsky DA, Holbrook JT, Wise RA, Shade DM, Irvin CG. Allergic rhinitis and sinusitis in asthma: differential effects on symptoms and pulmonary function. Chest 2006; 130:429-35.

44. Mascia K, Borish L, Patrie J, Hunt J, Phillips CD, Steinke JW. Chronic hyperplastic eosinophilic sinusitis as a predictor of aspirin-exacerbated respiratory disease. Ann Allergy Asthma Immunol 2005; 94:652-7.

45. Ishida A, Ohta N, Suzuki Y, Kakehata S, Okubo K, Ikeda H, et al. Expression of Pendrin and Periostin in Allergic Rhinitis and Chronic Rhinosinusitis. Allergol Int 2012; 61: 589-95.

46. Japanese Society of Allergology, Asthma Guideline Committee. Asthma Prevention and Management Guidelines 2012. Tokyo: Kyowa Kikaku; 2012 (in Japanese)

47. Wang ML, Gunel E, Petsonk EL. Design strategies for longitudinal spirometry studies: study duration and measurement frequency. Am J Respir Crit Care Med 2000; 162:2134-8. 
Table 1. Contents of the self-completed questionnaire

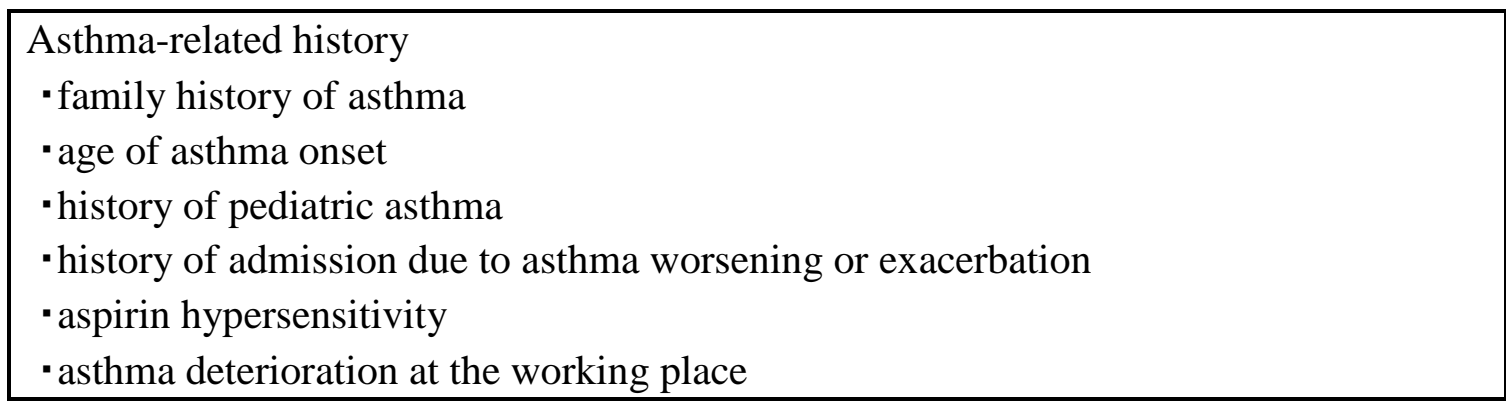

Comorbidity or a history of the following diseases

- allergic dermatitis - cardiovascular diseases including ischemic heart disease

- allergic rhinitis -gastrointestinal diseases including GERD

- seasonal rhinitis $\quad$ collagen vascular diseases including rheumatoid arthritis

- allergic conjunctivitis -diabetes mellitus

- chronic sinusitis - pulmonary diseases other than asthma

- other diseases including malignancy

Lifestyle and environment

- smoking history $\quad$ a highway near the home

- pet breeding -age at menopause

- type of occupation

Adherence to medication, sputum production, and exacerbations

- How often do you forget to take inhaled corticosteroids or other medications?

0: never, 1: seldom, 2: sometimes, 3: often, 4: always

- How often do you produce sputum?

0 : never, 1 : once in a few days, 2: every morning, 3: every morning and daytime

- How often did you receive systemic steroids due to asthma exacerbations during the recent 6 months?

0: never, 1: once, 2: twice or more 


\begin{tabular}{|c|c|}
\hline Sex (males/ females), $\mathrm{n}$ & $53 / 171$ \\
\hline Age at enrollment, years & $62.3(13.7)$ \\
\hline Age at asthma onset, years & $42.0(19.0)$ \\
\hline Body mass index $\left(\mathrm{kg} / \mathrm{m}^{2}\right)$ & $23.1(3.5)$ \\
\hline Smoking history (never), $\mathrm{n}$ & 181 \\
\hline Atopic predisposition ${ }^{*}, \%$ & 70 \\
\hline Pediatric asthma (none/ recurrent/ persistent), $\%$ & $81 / 8 / 11$ \\
\hline Disease duration, years & $20.2(14.5)$ \\
\hline ICS-untreated period, years & $9.2(13.1)$ \\
\hline ICS daily maintenance dose ${ }^{\dagger}, \mu \mathrm{g}$ & $525(318)$ \\
\hline Number of other controller medications, $\mathrm{n}$ & $1.4(1.2)$ \\
\hline Treatment step $(2 / 3 / 4 / 5)^{\ddagger}, \%$ & $16 / 27 / 49 / 8$ \\
\hline Sputum production $(0 / 1 / 2 / 3)^{\S}, \%$ & $54 / 20 / 8 / 18$ \\
\hline Asthma Control Test, points & $22.6(3.5)$ \\
\hline History of admission due to asthma, $\mathrm{n}(\%)$ & $78(35)$ \\
\hline Allergic rhinitis, $\mathrm{n}(\%)$ & $129(58)$ \\
\hline Chronic sinusitis, $\mathrm{n}(\%)$ & $65(29)$ \\
\hline Blood neutrophils, \% & $60.1(10.0)$ \\
\hline eosinophils, \% & $5.2(4.9)$ \\
\hline Serum IgE, IU/mL & $180(0-16000)$ \\
\hline periostin, $\mathrm{ng} / \mathrm{mL}$ & $92.8(38.4)$ \\
\hline high sensitivity C-reactive protein, $\mathrm{mg} / \mathrm{L}$ & $1341(3147)$ \\
\hline eosinophil cationic protein, $\mu \mathrm{g} / \mathrm{L}$ & $15.1(29.3)$ \\
\hline $\mathrm{FEV}_{1}$ at the first measurement, $\mathrm{L}^{\mathbb{\pi}}$ & $2.11(0.69)$ \\
\hline$\%$ predicted $\mathrm{FEV}_{1}$ at the first measurement, $\%$ & $91.9(19.2)$ \\
\hline $\mathrm{FEV}_{1} / \mathrm{FVC}$ at the first measurement, $\%$ & $73.9(9.8)$ \\
\hline $\mathrm{FEV}_{1}$ at enrollment, $\mathrm{L}$ & $2.04(0.73)$ \\
\hline$\%$ predicted $\mathrm{FEV}_{1}$ at enrollment, \% & $97.4(22.2)$ \\
\hline $\mathrm{FEV}_{1} / \mathrm{FVC}$ at enrollment, $\%$ & $72.2(10.0)$ \\
\hline Reversibility at enrollment, $\%^{\#}$ & $3.8(6.0)$ \\
\hline
\end{tabular}
(range) for serum IgE. *Considered atopic when one or more specific IgE antibodies against cat or dog dander, weed, grass, or Japanese cedar pollens, moulds, or house dust mite were positive. ${ }^{\dagger}$ Equivalent to fluticasone propionate. ${ }^{\ddagger}$ according to the Global Initiative for Asthma 2010 guideline ${ }^{27} .{ }^{\S} 0=$ never, the details are shown in 


\begin{tabular}{|c|c|c|c|}
\hline & Estimates & $95 \%$ C.I. & $\bar{p}$ value \\
\hline Smoking history, ex vs. never & -8.48 & $-20.2,3.27$ & 0.16 \\
\hline Atopic predisposition & -1.10 & $-6.29,4.09$ & 0.68 \\
\hline Disease duration, years & -4.79 & $-18.4,8.86$ & 0.56 \\
\hline ICS-untreated period, years & 0.10 & $-0.24,0.45$ & 0.65 \\
\hline ICS daily maintenance dose, $\mu \mathrm{g}$ & -0.01 & $-0.03,0.001$ & 0.07 \\
\hline Number of other controller medications, $\mathrm{n}$ & -0.36 & $-4.21,3.49$ & 0.86 \\
\hline Adherence to medication, incomplete $v s$. complete ${ }^{*}$ & -4.56 & $-9.08,-0.04$ & 0.05 \\
\hline Treatment step, 5 vs. $2-4^{\dagger}$ & -7.77 & $-15.7,0.13$ & 0.05 \\
\hline Sputum production, never $v$ s. others ${ }^{\ddagger}$ & 0.99 & $-3.53,5.51$ & 0.67 \\
\hline Asthma Control Test, points & 1.53 & $0.29,2.77$ & 0.02 \\
\hline History of admission due to asthma & -4.49 & $-9.45,0.46$ & 0.08 \\
\hline Aspirin hypersensitivity & -6.52 & $-20.0,6.98$ & 0.34 \\
\hline Asthma deterioration at the working place & -12.2 & $-54.4,30.0$ & 0.57 \\
\hline Allergic rhinitis & -1.21 & $-5.88,3.45$ & 0.61 \\
\hline Allergic dermatitis & 4.51 & $-1.51,10.5$ & 0.14 \\
\hline Chronic sinusitis & -10.1 & $-19.8,-0.27$ & 0.04 \\
\hline Ischemic heart disease & 3.41 & $-16.6,23.4$ & 0.74 \\
\hline Hypertension & -3.79 & $-9.12,1.53$ & 0.16 \\
\hline Dyslipidemia & -3.67 & $-9.42,-2.06$ & 0.21 \\
\hline Diabetes mellitus & -8.03 & $-15.4,-0.67$ & 0.03 \\
\hline Gastro-esophageal reflux disease & -3.85 & $-9.89,2.19$ & 0.21 \\
\hline Malignancy & -3.44 & $-26.0,19.1$ & 0.76 \\
\hline Post-menopause & 5.05 & $-14.2,24.3$ & 0.60 \\
\hline Pet breeding & -0.28 & $-12.6,12.0$ & 0.96 \\
\hline Log blood neutrophils, $\%$ & -7.40 & $-69.1,54.3$ & 0.81 \\
\hline eosinophils, \% & -0.67 & $-1.60,0.27$ & 0.16 \\
\hline Log serum IgE, IU/mL & -2.85 & $-9.74,4.04$ & 0.42 \\
\hline periostin, $\mathrm{ng} / \mathrm{mL}$ & -29.1 & $-56.2,-1.97$ & 0.04 \\
\hline high sensitivity C-reactive protein, $\mathrm{mg} / \mathrm{L}$ & -1.88 & $-9.85,6.10$ & 0.64 \\
\hline eosinophil cationic protein, $\mu \mathrm{g} / \mathrm{L}$ & -4.47 & $-15.7,6.81$ & 0.44 \\
\hline Periostin group, high $v s$. low ${ }^{\S}$ & -6.96 & $-11.4,-2.51$ & 0.002 \\
\hline
\end{tabular}


570 Table 4. Estimated effects of clinical indices and serum periostin on a decline in $\mathrm{FEV}_{1}$ of $571 \quad \mathbf{3 0} \mathbf{~} \mathbf{L} \cdot \mathbf{y r}^{-1}$ or greater

\begin{tabular}{lllllll}
\hline & \multicolumn{3}{l}{ Univariate analysis } & \multicolumn{3}{l}{ Multivariate analysis } \\
\cline { 2 - 7 } & Estimates & $95 \%$ C.I. & p value & Estimates & 95\% C.I. & p value \\
\cline { 2 - 7 } Treatment step, 5 $v s .2-4^{*}$ & 1.63 & $0.51,2.60$ & 0.004 & 1.24 & $0.078,2.30$ & 0.04 \\
History of admission due to asthma & 1.09 & $0.37,1.90$ & 0.003 & 0.70 & $-0.11,1.50$ & 0.09 \\
ICS daily maintenance dose, $\mu \mathrm{g}$ & 0.001 & $0.00,0.002$ & 0.01 & - & & \\
Chronic sinusitis & 0.82 & $0.11,1.53$ & 0.03 & 0.61 & $-0.15,1.37$ & 0.12 \\
Smoking history, ex $v s$. never & 0.87 & $-0.002,1.74$ & 0.05 & 0.98 & $0.030,1.93$ & 0.04 \\
Log serum periostin, ng/mL $_{\text {Periostin group, high } v s . \text { low }^{\dagger}}$ & 2.96 & $0.78,5.13$ & 0.008 & - & & \\
\end{tabular}

572 Estimated effects were adjusted by sex, height, age at enrollment, and $\mathrm{FEV}_{1}$ at the first measurement.

$573 \quad$ according to the Global Initiative for Asthma 2010 guideline ${ }^{27}$.

$574{ }^{\dagger}$ Patients were stratified into two groups according to their serum periostin levels: high $\geq 95 \mathrm{ng} / \mathrm{mL}$, low $<$

$57595 \mathrm{ng} / \mathrm{mL}$. ICS: inhaled corticosteroids, C.I.: confidence interval

576 ICS daily maintenance dose was excluded from multivariate analysis because of its strong correlation with

577 treatment step.

578 
579 Table 5. Frequencies of 3 tag SNPs and analysis results using dominant and recessive models 580 for serum periostin levels and frequency of rapid decliners*

\begin{tabular}{|c|c|c|c|c|c|c|c|c|}
\hline & & & & & Serum peri & stin levels & $\begin{array}{l}\text { Frequency } \\
\text { rapid declin }\end{array}$ & \\
\hline & & & & & $\mathrm{p}$ value & & $\mathrm{p}$ value & \\
\hline Tag SNP & Genotype & $\mathrm{n}(\%)$ & Allelic & $\mathrm{n}(\%)$ & Dominant $^{\dagger}$ & Recessive $^{\ddagger}$ & Dominant $^{\dagger}$ & Recessive $^{\ddagger}$ \\
\hline rs1028728 & AA & $164(74)$ & $\mathrm{A}$ & $383(86)$ & & & & \\
\hline & AT & $55(25)$ & $\mathrm{T}$ & $63(14)$ & 0.40 & 0.46 & 0.17 & 0.14 \\
\hline & $\mathrm{TT}$ & $4(2)$ & & & & & & \\
\hline rs3829365 & GG & $113(51)$ & $\mathrm{G}$ & $316(71)$ & & & & \\
\hline & $\mathrm{GC}$ & $90(40)$ & $\mathrm{C}$ & $130(29)$ & 0.003 & 0.70 & 0.40 & 0.33 \\
\hline & $\mathrm{CC}$ & $20(9)$ & & & & & & \\
\hline rs9603226 & GG & $107(48)$ & G & $311(70)$ & & & & \\
\hline & $\mathrm{AG}$ & $97(44)$ & A & $135(30)$ & 0.80 & 0.33 & 0.01 & 0.81 \\
\hline & AA & $19(9)$ & & & & & & \\
\hline
\end{tabular}

$581{ }^{*}$ defined as patients who showed a decline in $\mathrm{FEV}_{1}$ of $30 \mathrm{~mL} \cdot \mathrm{yr}^{-1}$ or greater

$582{ }^{\dagger}$ Assuming that heterozygotes have the same increased risk as minor homozygous genotypes.

$583 \quad{ }^{\ddagger}$ Assuming that heterozygotes have no increased risk.

584 


\section{$585 \quad$ Figure legends}

586 Figure 1. Three tag SNPs that determine 4 major haplotypes of the POSTN gene and

587 haplotype frequencies in the Japanese population are presented.

588 *at intron 66 bp upstream of exon 21

589

590 Figure 2. Relationships between serum periostin levels and blood eosinophil counts (left) or 591 serum IgE levels (right).

592 Presented in logarithmic scales on both the X-and Y-axes. 


\begin{tabular}{|c|c|c|c|c|}
\hline & 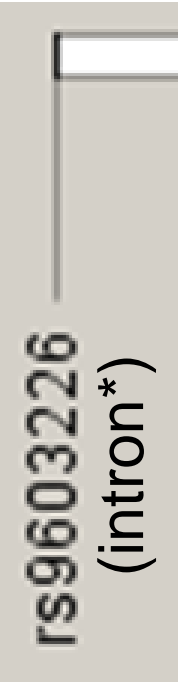 & 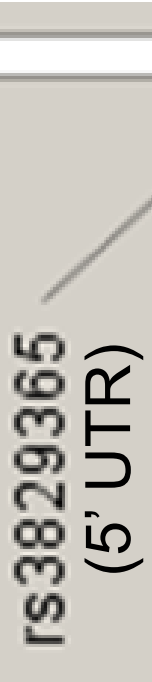 & 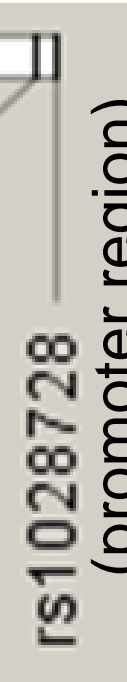 & Frequency \\
\hline Haplotype 1 & $A$ & G & $A$ & 0.322 \\
\hline Haplotvpe 2 & $G$ & C & $A$ & 0.278 \\
\hline Haplotype 3 & $G$ & $G$ & $\mathrm{~T}$ & 0.133 \\
\hline laplotype 4 & G & $G$ & A & 0.267 \\
\hline
\end{tabular}

Figure 1. 

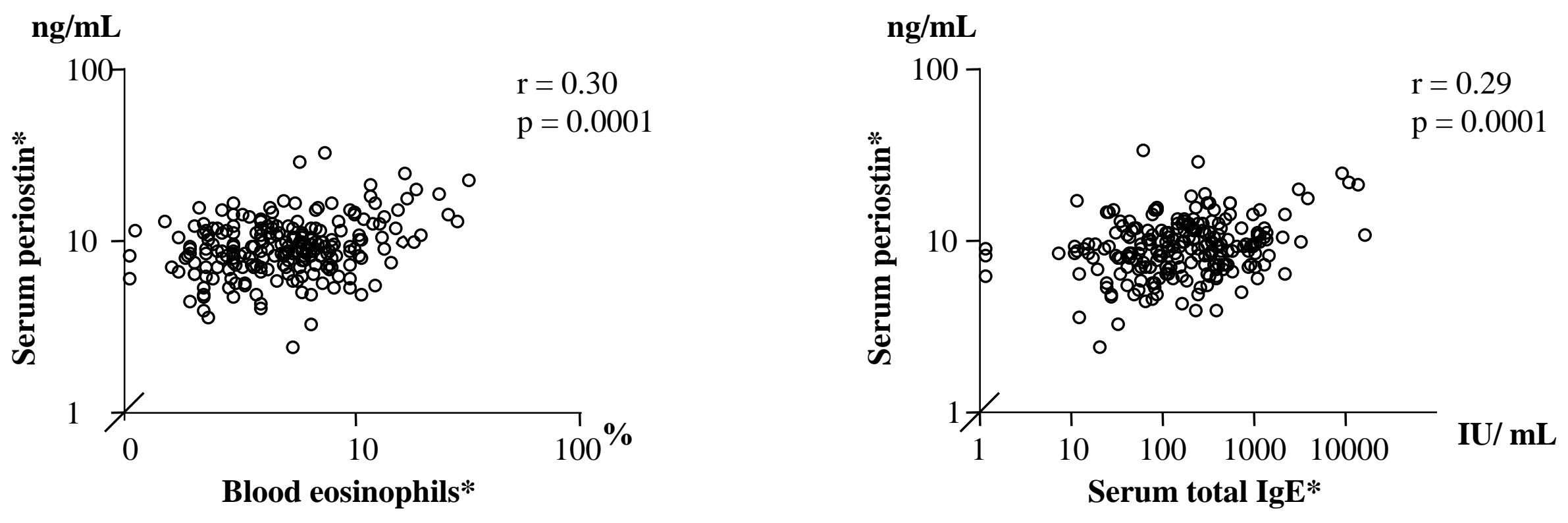

Figure 2. 


\section{Online Repository}

2 Increased periostin associates with greater airflow limitation in patients receiving 3 inhaled corticosteroids

4

5 Yoshihiro Kanemitsu $\mathrm{MD}^{*^{1,2}}$, Hisako Matsumoto $\mathrm{MD}, \mathrm{PhD}^{*^{1,2}}$, Kenji Izuhara

$6 \mathrm{MD}, \mathrm{PhD}^{3}$, Yuji Tohda MD, $\mathrm{PhD}^{2,4}$, Hideo Kita MD, $\mathrm{PhD}^{2,5}$, Takahiko Horiguchi MD,

$7 \quad \mathrm{PhD}^{2,6}$, Kazunobu Kuwahara $\mathrm{MD}, \mathrm{PhD}^{2,6}$, Keisuke Tomii $\mathrm{MD}, \mathrm{PhD}^{2,7}$, Kojiro Otsuka

$8 \mathrm{MD}, \mathrm{PhD}^{1,2,7}$, Masaki Fujimura MD, $\mathrm{PhD}^{2,8}$, Noriyuki Ohkura $\mathrm{MD}^{2,8}$, Katsuyuki Tomita

$9 \mathrm{MD}, \mathrm{PhD}^{2,4}$, Akihito Yokoyama MD, $\mathrm{PhD}^{2,9}$, Hiroshi Ohnishi $\mathrm{MD}, \mathrm{PhD}^{2,9}$, Yasutaka

10 Nakano $\mathrm{MD}, \mathrm{PhD}^{2,10}$, Tetsuya Oguma $\mathrm{MD}, \mathrm{PhD}^{2,10}$, Soichiro Hozawa $\mathrm{MD}, \mathrm{PhD}^{2,11}$,

11 Tadao Nagasaki MD ${ }^{1}$, Isao Ito $\mathrm{MD}, \mathrm{PhD}^{1}$, Tsuyoshi Oguma $\mathrm{MD}^{1}$, Hideki Inoue $\mathrm{MD}^{1}$,

12 Tomoko Tajiri $\mathrm{MD}^{1}$, Toshiyuki Iwata $\mathrm{MD}^{1}$, Yumi Izuhara $\mathrm{MD}^{1}$, Junya Ono $\mathrm{BS}^{12}$,

13 Shoichiro Ohta $\mathrm{MD}, \mathrm{PhD}^{13}$, Mayumi Tamari $\mathrm{MD}, \mathrm{PhD}^{14}$, Tomomitsu Hirota DDS,

$14 \mathrm{PhD}^{14}$, Tetsuji Yokoyama $\mathrm{MD}, \mathrm{PhD}^{15}$, Akio Niimi MD, $\mathrm{PhD}^{1,2,16}$ and Michiaki Mishima

$15 \mathrm{MD}, \mathrm{PhD}^{1,2}$.

16 Affiliations

$17{ }^{1}$ Department of Respiratory Medicine, Graduate School of Medicine, Kyoto University, 18 Kyoto, Japan.

$19{ }^{2}$ Kinki Hokuriku Airway disease Conference (KiHAC)

$20{ }^{3}$ Division of Medical Biochemistry, Department of Biomolecular Sciences, Saga 21 Medical School, Saga, Japan.

$22{ }^{4}$ Department of Respiratory Medicine and Allergology, Faculty of Medicine, Kinki 23 University, Osaka, Japan.

$24{ }^{5}$ Department of Respiratory Medicine, Takatsuki Red Cross Hospital, Osaka, Japan.

${ }^{6}$ Department of Respiratory Internal Medicine, Fujita Health University Second 
Educational Hospital, Aichi, Japan.

${ }^{7}$ Department of Respiratory Medicine, Kobe City Medical Center General Hospital, Hyogo, Japan.

${ }^{8}$ Department of Respiratory Medicine, Cellular Transplantation Biology, Kanazawa University Graduate School of Medicine, Kanazawa, Japan.

9 Department of Hematology and Respiratory Medicine, Kochi University, Kochi, 32 Japan.

${ }^{10}$ Division of Respiratory Medicine, Department of Internal Medicine, Shiga University of Medical Science, Shiga, Japan.

${ }^{11}$ Hiroshima Allergy and Respiratory Clinic, Hiroshima, Japan.

${ }^{12}$ Shino-Test Corporation, Kanagawa, Japan.

${ }^{13}$ Department of Laboratory Medicine, Saga Medical School, Saga, Japan.

14 Laboratory for Respiratory Diseases, Center for Genomic Medicine, RIKEN,

Yokohama, Kanagawa, Japan.

${ }^{15}$ Department of Health Promotion, National Institute of Public Health, Wako, Saitama, Japan

${ }^{16}$ Department of Medical Oncology and Immunology, Nagoya City University School of Medical Sciences, Aichi, Japan.

*YK and HM similarly contributed to this study.

Correspondence should be addressed to Hisako Matsumoto M.D., Ph.D.,

Department of Respiratory Medicine, Graduate School of Medicine, Kyoto University,

53 Kawahara-cho, Shogoin, Sakyo-ku, Kyoto 606-8507, Japan. 
50 E-mail: hmatsumo@kuhp.kyoto-u.ac.jp 
52

53

54

55

\section{Methods}

\section{Patients}

Patients with asthma were recruited from nine institutions belonging to the Kinki Hokuriku Airway disease Conference where asthma specialists manage patients, including six university hospitals, two satellite general hospitals, and one satellite clinic. Asthma was diagnosed according to the American Thoracic Society criteria ${ }^{\mathrm{E} 1}$ on the basis of a history of recurrent episodes of wheezing and chest tightness with or without cough and documented airway reversibility to a bronchodilator or hyper-responsiveness to inhaled methacholine. From September 2009 to December 2011, patients were enrolled if they had received ICS treatment for 4 years or more, undergone three or more pulmonary function tests when they were stable, and were free from exacerbations for at least one month. The first pulmonary function test was performed at least one year after the commencement of ICS treatment and at 25 years of age or older. Patients who had smoked more than 10 pack-years, smoked in the past one year, or had other pulmonary diseases were excluded.

\section{Self-completed questionnaire and clinical indices}

The self-completed questionnaire was composed of 4 major items, as presented in Table 1.

Adherence to ICS or other medications, frequency of sputum production, and requirement for systemic corticosteroids during the last 6 months were graded as shown in Table 1. The Asthma Control Test $(\mathrm{ACT})^{\mathrm{TM}}$ was also scored. Duration of ICS treatment and details on medication at enrollment were recorded from medical charts by patients' physicians. The treatment step at enrollment was determined according to the 
Global Initiative for Asthma 2010 guideline $^{\mathrm{E} 2}$.

\section{Measurement of systemic biomarkers}

Blood eosinophil and neutrophil counts, and serum levels of total immunoglobulin E (IgE) (ImmunoCAP ${ }^{\circledR}$ total IgE, Phadia K.K., Tokyo, Japan), specific IgE against common inhaled allergens (ImmunoCAP ${ }^{\circledR}$ specific $\operatorname{IgE}$ ), eosinophil cationic protein $(\mathrm{ECP})\left(\mathrm{ImmunoCAP}{ }^{\circledR} \mathrm{ECP}\right)$, high sensitivity $\mathrm{C}$-reactive protein (hsCRP) (CardioPhase ${ }^{\circledR}$ hsCRP, Siemens Healthcare Diagnostics K.K., Tokyo, Japan), and periostin were determined.

Serum periostin levels were measured using an enzyme-linked immunosorbent assay at Shino-test (Kanagawa, Japan), as described previously ${ }^{\mathrm{E} 3}$. Briefly, two rat anti-human periostin monoclonal antibodies (SS18A and SS17B) were used. SS18A and SS17B are antibodies against the first and fourth FAS I domains, respectively. Intra- and inter-assay coefficients of variation ranged from $1.31 \%$ to $2.54 \%$ and $1.49 \%$ to $2.01 \%$, respectively.

\section{Haplotype analysis, DNA extraction, and genotyping of the POSTN gene}

A total of 47 single-nucleotide polymorphisms (SNPs) in the region of the POSTN gene and its upstream, total $39 \mathrm{~kb}$, was captured in the HapMap Japanese data set with minor allele frequencies $>0.10$. Pairwise tagging was performed at $r^{2}>0.8$ using a tagger in Haploview 4.2 software. Haplotype analysis identified 4 major haplotypes and 2 minor haplotypes. Two minor haplotypes were grouped into the closest major haplotype, and 3 tag SNPs that determined the 4 haplotypes were identified (Figure 1). These 3 tag SNPs were located at promoter region (rs1028728), 5'UTR 
100 region (rs3829365), and at intron $66 \mathrm{bp}$ upstream of exon 21 (rs9603226). The

101 frequencies of the minor alleles in the Japanese population were 0.136 (rs1028728),

$102 \quad 0.278(\mathrm{rs} 3829365)$, and 0.330 (rs9603226).

103 Genomic DNA was isolated from blood cells using a QIAamp DNA Blood Mini

104 Kit (Qiagen, Tokyo, Japan). SNPs were genotyped using a Taqman genotyping assay

105 according to the manufacturer's instructions (Applied Biosystems, Tokyo, Japan) and

106 analyzed using an Applied Biosystems 7300 Real-Time PCR System (Applied

107 Biosystems).

108 


\section{References}

110 E1. Standards for the diagnosis and care of patients with chronic obstructive pulmonary disease (COPD) and asthma. This official statement of the American Thoracic Society was adopted by the ATS Board of Directors, November 1986. Am Rev Respir Dis 1987; 136:225-44.

E2 Global Strategy for Asthma Management and Prevention, Global Initiative for Asthma (GINA) 2010. Available from: Global Strategy for Asthma Management and Prevention, Global Initiative for Asthma (GINA) 2010. Available from: http://www.ginasthma.org.

E3. Okamoto M, Hoshino T, Kitasato Y, Sakazaki Y, Kawayama T, Fujimoto K, et al. Periostin, a matrix protein, is a novel biomarker for idiopathic interstitial pneumonias. Eur Respir J 2011; 37:1119-27. 
124 Figure legends

125

126 Figure $\mathrm{E} 1$. The distribution of $\Delta \mathrm{FEV}_{1}$ in the study population

127

128 Figure E2. ROC curve analysis of serum periostin levels comparing asthmatic patients

129 and healthy subjects, in which the cutoffs of $95 \mathrm{ng} / \mathrm{mL}, 80 \mathrm{ng} / \mathrm{mL}, 92 \mathrm{ng} / \mathrm{mL}$, and 100

$130 \mathrm{ng} / \mathrm{mL}$ are presented with arrows. 




Figure E1. 




Figure E2. 